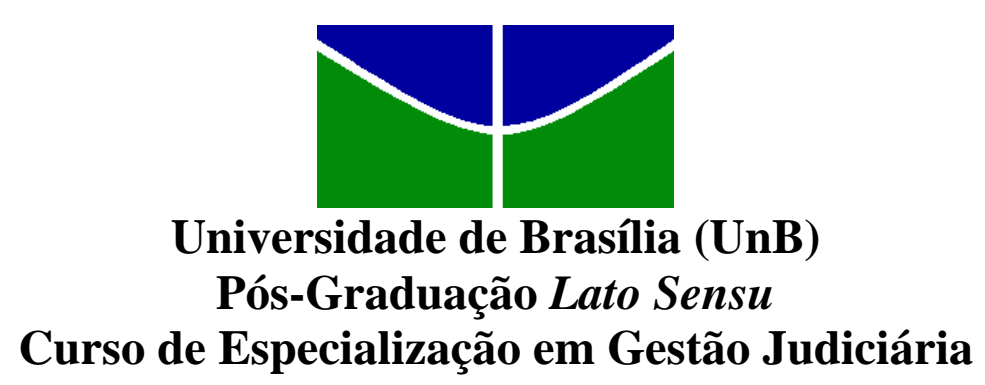

\title{
PERCEPÇÃO DE SERVIDORES DO SUPERIOR TRIBUNAL DE JUSTIÇA ACERCA DA MOTIVAÇÃO NO TRABALHO
}

AUTOR: JOSÉ LUIZ CUNHA ABREU

ORIENTADOR: PROF $^{\circ}$ MSC. ANTONIO ISIDRO FILHO

Brasília - DF

2009 


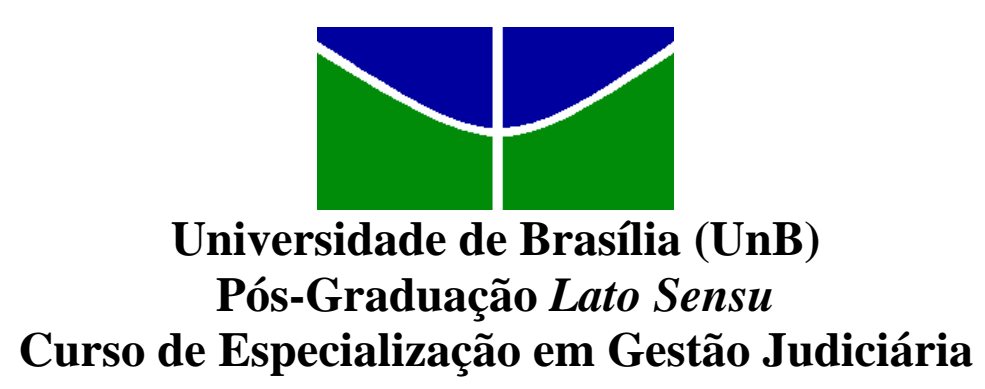

\title{
PERCEPÇÃO DE SERVIDORES DO SUPERIOR TRIBUNAL DE JUSTIÇA ACERCA DA MOTIVAÇÃO NO TRABALHO
}

\author{
AUTOR: JOSÉ LUIZ CUNHA ABREU
}

ORIENTADOR: PROF ${ }^{\circ}$ MSC. ANTONIO ISIDRO FILHO

Monografia apresentada à Faculdade de Economia, Administração, Contabilidade e Ciência da Informação e Documentação (FACE) da Universidade de Brasília - UNB, como requisito parcial à obtenção do grau de Especialista em Gestão Judiciária.

Brasília - DF 


\section{DEDICATÓRIA}

Dedico esse estudo, primeiramente a Deus, pois me deu forças para sempre seguir em frente.

Dedico a minha mulher e companheira Yara Alice.

Dedico ao meu filho Renato.

Dedico às minhas amigas Fernanda da Cunha Pacheco e Lígia Augusto Freitas Campos de Oliveira

E dedico ao meu orientador professor Isidro, que me deu coragem e ânimo para chegar até o final com sua orientação precisa e competente. 


\section{AGRADECIMENTOS}

Agradeço ao Superior Tribunal de Justiça por ter me dado essa grande oportunidade de crescimento intelectual e profissional. Agradeço aos professores da Universidade de Brasília - UNB que fizeram parte do $1^{\circ}$ curso de especialização em Gestão Judiciária. 


\section{SUMÁRIO}



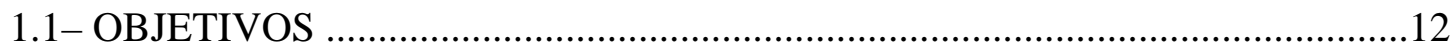

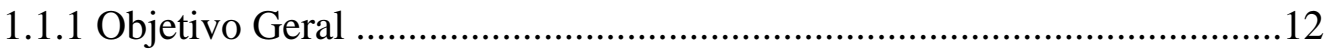

1.1.2 Objetivos Específicos ........................................................................12

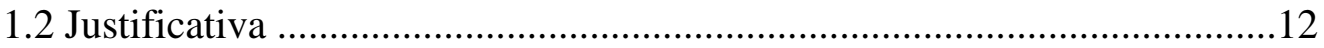

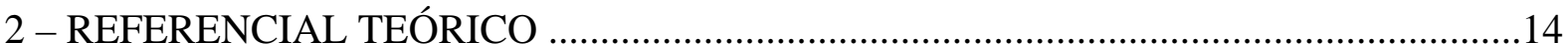

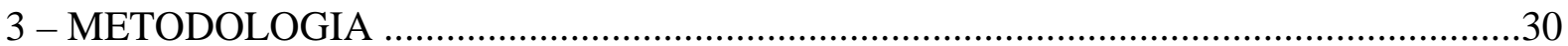

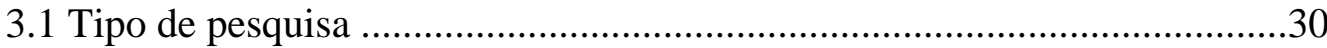

3.2 População e Amostra.................................................................................30

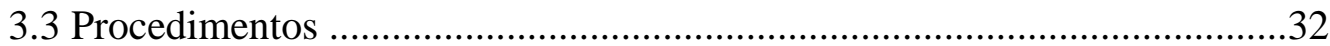

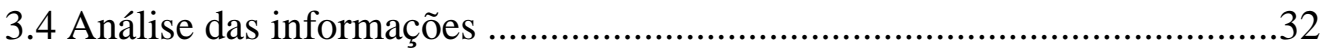

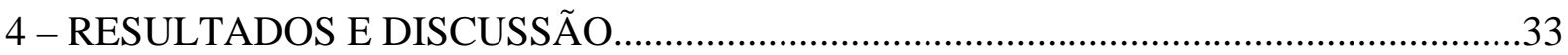

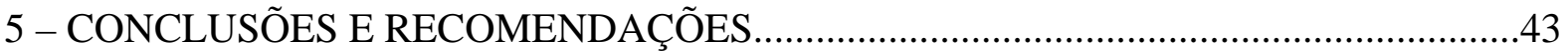

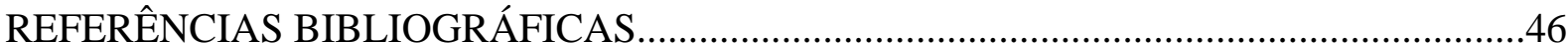




\section{1 -INTRODUÇÃO}

Atualmente existem muitas definições e estudos voltados para o que é a motivação, e o que leva as pessoas a seguirem trabalhando em busca de uma satisfação valorativa de suas expectativas e aspirações pessoais.

Interessou-me pesquisar e compreender o que motiva os servidores do Superior Tribunal de Justiça, para dar subsídios àqueles que são os gestores, fornecendo um norte no sentido de oferecer-lhes meio para que o servidor sinta-se mais motivado no trabalho realizado no Tribunal. O presente estudo contribui para que esses mesmos gestores e demais clientes possam praticar suas ações gerenciais de forma equânime, democrática e igualitária.

\section{O que Significa Realmente a Motivação?}

Segundo Chiavenato (1999): "a motivação é o desejo de exercer altos níveis de esforço em direção a determinados objetivos organizacionais, condicionados pela capacidade de satisfazer objetivos individuais. A motivação depende da direção (objetivos), força e intensidade do comportamento (esforço) e duração e persistência.

Quem é responsável pela motivação das pessoas dentro de um ambiente organizacional? Deve ser a própria pessoa que deve se auto-abastecer de motivação pessoal ou a motivação é uma função gerencial? Chiavenato (1999) sugere a segunda colocação. Argumenta que a motivação está contida dentro das próprias pessoas e pode ser amplamente influenciada por fontes externas ao indivíduo ou pelo seu próprio trabalho na empresa.

O gerente deve saber como extrair do ambiente de trabalho as condições externas para elevar a satisfação profissional. 
Segundo Robbins (1998), fica evidente a função do gerente de motivar o empregado. Isso fica evidenciado na colocação em que os empregados têm necessidades diferentes e, portanto, não devem ser tratados da mesma forma. Devem ser estabelecidos metas e dados bem como os respectivos feedbacks sobre seu progresso. Os empregados devem participar de decisões que os afetem, com o objetivo de motivá-los a aumentar a produtividade, o compromisso de trabalhar metas, a motivação e a satisfação do empregado no trabalho.

A motivação existe dentro das pessoas e se dinamiza através das necessidades humanas. Todas as pessoas têm suas necessidades próprias, que podem ser chamadas de desejos, aspirações, objetivos individuais ou motivos. Certas necessidades são basicamente semelhantes quanto à maneira pela qual fazem as pessoas organizarem seu comportamento para obter satisfação.

Ainda não se sabe distinguir entre o que é causa e o que é efeito no comportamento motivado. E também não se descobriu se o comportamento é causado por fatores intrínsecos ou extrínsecos ao indivíduo ou ao grupo. As diferenças entre as pessoas dificultam enormemente a definição de parâmetros universais que as empresas possam utilizar para motivar as pessoas em igualdade de condições. Há sempre um componente subjetivo na motivação que provoca uma enorme complicação. A motivação funciona como um dinamizador, um impulsionador do comportamento humano.

O indivíduo passa pela seleção, submete-se à ação do treinamento, mas falta ainda uma das fases mais importantes: a fase de ação do comportamento.

Um colaborador poderá estar dotado generosamente de todas as qualidades necessárias ao desempenho do cargo, ter as ferramentas necessárias, ter um bom ambiente de trabalho. Mas isto não garantirá, de antemão, que ele executará a contento sua tarefa. A misteriosa 
qualidade que o leva a empreender a ação para executar a tarefa está diretamente ligada aos problemas da motivação humana na empresa. Uma pessoa altamente motivada trabalhará com afinco para atingir metas de desempenho. Com habilidade e entendimento adequados de sua função, ela será altamente produtiva.

Em uma sociedade de produção em massa, o empreendimento de motivar as pessoas a trabalhar não constitui uma tarefa fácil, visto que muitas obtêm pouca satisfação pessoal dos seus empregos e auferem pouco senso de realização e criatividade.

É preciso, de início, diferenciar necessidade, incentivo e motivação. As necessidades são os desejos sentidos pelo indivíduo. São chamadas também de exigências ou imperativos. Os incentivos são os objetos ou os comportamentos que satisfazem as necessidades.

Muitos fatores podem impedir que uma pessoa tenha altos desempenhos. Um vendedor altamente motivado pode trabalhar sessenta horas por semana, mas ter dificuldade em atingir suas metas de desempenho por vários motivos. Pode não entender seus clientes ou seus produtos, pode trabalhar para uma empresa sem reputação ter de vender produtos inferiores a preços absurdos, ter dificuldade no campo de vendas, ou ser perturbado por épocas de recessão na economia.

Administradores eficientes facilitam o desempenho fornecendo as coisas de que as pessoas precisam para desempenhar sua função. Podem oferecer a seu pessoal treinamento adequado, ferramentas e equipamentos necessários, orçamentos apropriados, pessoais de apoio, autoridade e informação suficientes para que o pessoal faça um bom trabalho. Sem esses elementos, até mesmo as pessoas altamente motivadas não vão ter um bom desempenho. Assim, ao perceberem que a situação inibe em vez de auxiliar seu desempenho, perdem a motivação. 
Ainda buscando compreender a motivação, dentre muitos outros conceitos buscados, pode ser definida como uma ação dirigida a objetivos, sendo auto-regulada, biológica ou cognitivamente, persistente no tempo e ativada por um conjunto de necessidades, emoções, valores, metas e expectativas (HONTANGAS; SALANOVA; PEIRÓ, 1996, p.16).

Nesse sentido tem-se como referência a Teoria das Expectativas, elaborada por Vroom (1964). Esta teoria, segundo Muchinsky (1994), consagrou o conceito de expectativas no campo da motivação. É uma teoria cognitiva e admite existir uma relação entre o esforço que se realiza e o rendimento do trabalho.

Tal teoria se sustenta em cinco conceitos básicos (MUCHINSKY, 1994; HOTANGA; SALANOVA; PEIRÓ, 2002; VROOM, 1964):

1. Resultados do trabalho, que são as conseqüências que uma organização pode oferecer a seus empregados a partir do exercício de suas funções;

2. Valência, que consiste na atribuição a cada resultado do trabalho de desejabilidade ou não;

3. Expectativa, que consiste na percepção de quanto os esforços despendidos conduz aos resultados esperados ou, em outras palavras, consiste na prevenção do indivíduo sobre a probabilidade de certo resultado (desejável ou não) venha de fato ocorrer;

4. Instrumentalidade, que consiste no grau de relação percebida entre a execução e a obtenção dos resultados e

5. Força motivacional, que é, então, a quantidade de esforço ou pressão de uma pessoa para motivar-se. Desde Vroom (1964), a força motivacional é uma função multiplicativa das valências, instrumentalidade e expectativas.

Os eventos organizacionais que expressam baixos níveis de comprometimento como o absenteísmo e a rotatividade, podem ser explicados por meio da Teoria da Expectância. A ação voluntária de se desligar do quadro funcional de uma organização pode ser compreendida pela alegação de que as recompensas percebidas são inadequadas; de que as recompensas são desiguais, quando comparadas às de outras pessoas que desempenham atividades semelhantes ou, ainda, de que é inviável atingir as metas que foram previamente estabelecidas (abordagem da expectativa) (BOWDITCH, BUONO, 1992, apud GONDIM; SILVA, 2004). 
Para Gondim e Silva (2004), a crença compartilhada pelos pesquisadores sobre a importância da motivação para o desempenho no trabalho, associada ao reconhecimento da complexidade desse fenômeno e do limitado poder explicativo das teorias da motivação, contribuíram muito para a incorporação de conceitos e teorias que a rigor não estariam diretamente envolvidos na discussão do tema, o que vem dificultando sua delimitação teórica no campo de estudos do comportamento organizacional. Segundo os autores, como se admite que a ação humana é cada vez mais multicausal e contextual, envolvendo aspectos biológicos, psicológicos, históricos, sociológicos e culturais, as pesquisas sobre motivação passaram a utilizar múltiplos critérios de mensuração, procurando relacionar esse conceito com tantos outros que poderiam dar conta de tal complexidade e que permitissem a ampliação da compreensão da conduta humana.

Segundo Ambrose e Kulik, 1999 (apud Gondim; Silva, 2004), motivação começou a estar associada a vários outros conceitos, tais como, satisfação, desejo, energia, recompensas intrínsecas e extrínsecas, comprometimento, envolvimento, ajustamento no trabalho, reforço, drive, necessidade, desenho de cargo, crenças, valores, metas, expectativa e, mais recentemente, criatividade, cultura, afeto e trabalho em equipes.

Spector (2008) afirma que a motivação é um conceito em psicologia que tem sido intensamente discutido há pelo menos um século, mas ainda é de difícil definição. Para ele, é geralmente descrita como um estado interior que induz uma pessoa a assumir determinados tipos de comportamento. Vista por uma perspectiva, ela tem a ver com a direção, intensidade e persistência de um comportamento ao longo do tempo. A direção refere-se à escolha de comportamentos específicos dentro de uma série de comportamentos possíveis; por exemplo, um funcionário pode decidir ir ao trabalho em um determinado dia, em vez de ligar para a empresa dizendo estar doente e fazer alguma outra coisa, como assistir à televisão, fazer compras ou visitar um amigo. A intensidade se refere ao esforço que uma pessoa empenha na realização de uma tarefa. A persistência diz respeito ao contínuo engajamento em um determinado tipo de comportamento ao longo do tempo.

Mesmo sem a avaliação dos números da pesquisa percebo que os servidores do Superior Tribunal de Justiça encaixam-se nessa definição. Todos, em geral, a meu ver, seguem uma direção de empenho em suas atividades com total comprometimento com a instituição agindo com muita intensidade no trabalho dado ao grande número de demandas judiciais que recaem em todos os setores do Tribunal e persistem ao longo do tempo, visto 
que a Instituição conta com um grande número de servidores com longo tempo de trabalho, percebendo-se que muitos ficam na instituição até sua aposentadoria.

Mas é preciso inovar e motivar os servidores do STJ, pois como afirma Lévy-Leboyer (1994) as mesmas coisas não motivam mais as mesmas pessoas. Aqueles que eram muito motivados por sua vida profissional desinteressam-se dela em proveito de atividades fora do trabalho. Entendo isso como sendo uma indagação: será que se têm mais motivos para ir trabalhar ou prefere-se ficar na expectativa de que chegue logo o fim de semana para se poderem exercer outras atividades mais prazerosas?

Nesse sentido pode-se falar sobre o poder do entusiasmo. Peale (1967) afirma que se pode ir adiante e desenvolver uma qualidade de entusiasmo tão significativo e em tal profundidade que não decline ou se esgote, seja qual for a tensão que sofra. Segundo ele uma pessoa pode fazer de si própria, praticamente, o que deseja fazer, desde que o deseje com bastante intensidade e haja corretamente na direção desejada. Para isso nós gestores devemos fazer com que ela tenha motivação e possa acreditar em ser recompensada com aquilo que deseje obter com o fruto de seu trabalho.

Reis et. al. (2007) afirmam que alguns dirigentes de empresas vangloriam-se em dizer que em suas empresas existem equipes de verdade: todos são respeitosos uns com os outros, não existem conflitos e todos gostam de trabalhar juntos. Na verdade, trata-se de confrarias e não de equipes. Equipes de verdade conflitam, uma vez que seus membros estão comprometidos com os objetivos pactuados e estão dispostos a lutar por eles. Como observar isso no STJ? Os servidores estão motivados? Devemos sim ouvi-los. Há de haver esse conflito, tem que observar se existe essa harmonia ou se não existe alguma insatisfação que propicie, no futuro, conflitos.

Robbins (2005) afirma que o sucesso em um trabalho é facilitado ou obstruído pela existência ou ausência de recursos de apoio.

Afirma ainda que uma maneira popular de pensar o desempenho, mas um tanto simplista, é que ele é uma função (f) da interação entre capacidade (C) e motivação (M), ou seja, desempenho $=\mathrm{f}(\mathrm{C} \times \mathrm{M})$. Se um desses fatores for inadequado, o desempenho será afetado negativamente. Isso nos ajuda (segundo ele) a entender, por exemplo, como um atleta ou estudante de capacidade modesta, mas esforçado, consegue superar os resultados de seus colegas mais capacitados, porém preguiçosos. Assim, a inteligência e as habilidades de uma 
pessoa precisam ser consideradas para que possamos realmente entender e prever o desempenho de um trabalhador. Mas uma peça desse quebra-cabeça ainda está faltando. Precisamos incluir a oportunidade para o desempenho (O) em nossa equação: desempenho = $\mathrm{f}(\mathrm{CxMxO})$. Mesmo que um indivíduo seja capaz e esteja motivado, pode haver obstáculos que limitem seu desempenho.

Quando quisermos descobrir por que um funcionário não está apresentando um desempenho compatível com a capacidade que você acha que ele tem, observe o ambiente de trabalho para ver se ele fornece condições suficientes de apoio. O funcionário tem ferramentas, equipamentos e materiais adequados? Ele pode contar com condições favoráveis de trabalho, colegas cooperativos, regras e procedimentos facilitadores, informações suficientes para tomar decisões imediatamente relacionadas a suas tarefas, tempo suficientes para executar um bom trabalho e coisas assim? Caso contrário, seu desempenho será prejudicado. 


\subsection{OBJETIVOS}

\subsubsection{OBJETIVO GERAL}

O objetivo geral desta monografia é identificar a percepção existente, atualmente, dos servidores do Superior Tribunal de Justiça quanto à motivação em seu trabalho.

\subsubsection{OBJETIVOS ESPECÍFICOS}

1 - Identificar a percepção de servidores do STJ acerca dos aspectos esperados no trabalho;

2 - Identificar a percepção de servidores do STJ acerca das características do trabalho que ocorrem no contexto da organização.

\subsection{JUSTIFICATIVA}

É essencial saber o que motiva os servidores do Superior Tribunal de Justiça, o que é valoroso para cada um. Por se tratar de uma alta Corte da Justiça é necessário saber o quanto seus servidores sentem motivação ao lidar com processos, desempenhar seu papel de cidadão perante aqueles que utilizam o Poder Judiciário para ter uma resposta de suas demandas processuais. Diferentemente do setor privado, o Tribunal possui características peculiares de motivação. O salário praticamente é igual, diferenciando-se apenas no grau de chefias, mas num todo possui remunerações idênticas definidas no Plano de Carreiras dos Servidores do Poder Judiciário.

Freitas (2007) confirma que a motivação dos servidores é essencial. A abertura de concursos internos pode significar mais adesão ao esforço da equipe. Programas de ergonomia, planejamento familiar, planejamento financeiro, tudo isto pode estimular a colaboração. A Revista Exame, periodicamente, fornece a relação das 100 melhores empresas do Brasil para trabalhar. Ali estão práticas inteligentes de gestão, muitas delas perfeitamente aplicáveis ao setor público. O administrador deve conhecê-las e adotar as que sejam viáveis no Poder Judiciário. 
O presente estudo contribuirá para que os gestores e dirigentes do Tribunal possam observar de forma crítica e dinâmica os anseios e desejos de uma parte destes servidores ouvidos. 


\section{2 - REFERENCIAL TEÓRICO}

É necessário fazer um apanhado e analisar historicamente o que as teorias e diversos autores afirmam no aspecto da motivação para que se possa fazer desenvolver esse estudo de acordo com as expectativas motivacionais dos servidores do STJ.

Para Gondim e Silva (2004), se há algo que estimula a curiosidade humana é saber as razões das diferenças individuais que evidenciam as preferências e os interesses de cada pessoa. Afinal de contas, o que faz com que alguém perca uma noite de sono lendo um livro aparentemente entediante para outro leitor? O que faz também com que uma pessoa se sinta desafiada a dar resposta a um problema matemático de difícil solução e não consiga desviar sua atenção até resolvê-la, enquanto outra diante do mesmo problema decida por procurar colegas que possam lhe ensinar rapidamente os passos necessários para sua solução? Os psicólogos acreditam que grande parte das razões das diversidades das condutas individuais decorra de um processo denominado motivação.

As empresas anteriormente à revolução industrial, não se preocupavam com o fator motivação de seus funcionários. As unidades de produção eram pequenas e as técnicas de produção muito simples. O dia de trabalho era longo, mas não existiam, nitidamente, problemas que envolviam a utilização dos esforços humanos e da motivação. Talvez, até mesmo, por não existir sindicatos organizados naquela época.

Com o crescimento industrial, com o aumento de capitais, fábricas, maquinários começaram-se a busca por um aumento de produtividade. O funcionário passou a ter um maior destaque nos processos de produção. Para haver essa maior produção acreditava-se que o melhor incentivo seria um salário maior, quanto mais dinheiro maior seria a produção. 
Quem criou esse ideal foi Taylor. Todos os colaboradores são iguais, e a administração científica vai aumentar a satisfação do trabalhador - concepção tayloriana. O funcionário passou a ser remunerado em função da produção, com salários adicionais. No entanto, perceberam os funcionários que não podiam produzir além de certo nível, pois não podiam exceder as demandas do mercado, já que seriam despedidos. Entrou em jogo a necessidade de segurança.

As verdadeiras necessidades da motivação humana começaram a aparecer e a administração científica chegou a ter um número crescente de fracassos.

Para os autores de um modo geral, as teorias que se sustentam no conceito de necessidade partem da premissa de que há uma energia ou força que excita ou gera uma tensão interna no organismo, experimentada subjetivamente como um impulso ou desejo para agir de modo que se reduza a força deste mesmo impulso, tensão ou desejo. Essas teorias, em certo sentido, estariam interessadas em desvendar os aspectos individuais biológicos e psicológicos que desencadeariam impulso ou desejo; em outras palavras, a falta ou carência de algo a ser suprido.

Apareceu finalmente Elton Mayo, chamado para resolver fracassos numa indústria. Realizou Mayo uma série de experiências, reconhecendo que os colaboradores buscavam mais do que dinheiro no trabalho e necessitavam de outros estímulos. Verificou que eles desejavam pertencer a um grupo e ser considerado como membros significativos do mesmo. Quando os trabalhadores conseguem um sentimento mais do valor pessoal, participam das decisões que afetam o seu trabalho. Muitos incentivos estavam sendo incluídos, como segurança, afiliação, estima, interesse pelo trabalho e êxito. Mayo iniciou, assim, o movimento de relações humanas. 
Os trabalhos de Mayo serviram para mostrar que a produtividade aumentou porque os trabalhadores conseguiram, pelas experiências que realizou, um sentimento maior de valor pessoal: participação nas decisões que afetavam o seu trabalho; ter um envolvimento no próprio trabalho; sentir-se mais seguros no mesmo, devido ao tratamento permissivo e amistoso do experimentador; ter a oportunidade de ganhar mais dinheiro, devido ao sistema de recompensa como incentivo ao grupo.

O período em que compreende a Teoria Comportamental denominou-se "Era Industrial Neoclássica (1950-1990)", onde a ênfase nas pessoas teve seu início com a "Teoria das Relações Humanas".

Essa abordagem surgiu com os resultados da famosa experiência de Hawthorne, realizada na década de 1930 para pesquisar o efeito das condições ambientais sobre a produtividade do pessoal, no sentido de dar importância ao fator humano na organização e a necessidade de humanização e democratização das organizações.

As principais conclusões de Hawthorne foram: o trabalho é uma atividade tipicamente grupal; o operário não reage como indivíduo isolado; a tarefa da administração é formar líderes capazes de compreender, comunicar e persuadir; e a pessoa é motivada essencialmente pela necessidade do trabalho em equipe.

Com o impacto da "Teoria das Relações Humanas", os conceitos antigos, tais como: organização formal, disciplina, departamentalização; passam a ceder lugar para novos conceitos, como organização informal, liderança, motivação, grupos sociais, recompensas etc.

A maior contribuição da Teoria das Relações Humanas foi ressaltar a necessidade de boas relações humanas no ambiente de trabalho, o tratamento mais humano dado às pessoas, a adoção de uma administração mais participativa em que as pessoas possam ter um papel mais 
dinâmico. Como conseqüências dessa teoria surgem os líderes a fim de melhorar o tratamento dado às pessoas e propiciar um ambiente motivacional de trabalho mais favorável e amigável.

Portanto, os fatores básicos da Teoria das Relações Humanas são: organização tratada como grupo de pessoas; ênfase nas pessoas e grupos sociais; sistemas psicológicos motivacionais; liberdade e autonomia do empregado e confiança nas pessoas.

No decorrer da "Era Industrial Neoclássica" surge a Teoria Comportamental, a moderna sucessora da Teoria das Relações Humanas.

A Teoria Comportamental trouxe novos conceitos sobre motivação, liderança e comunicação, que alteravam completamente os rumos da teoria administrativa, tornando-a mais humana e amigável.

São muitas as teorias da motivação. A tradicional da motivação, surgida de um movimento científico da administração na virada do século, baseia-se na suposição de que o dinheiro é o principal motivador. Se a recompensa financeira for grande, os trabalhadores produzirão mais. Desse modo, ela deve estar relacionada diretamente ao desempenho.

As décadas de 1940 a 1960 foram consideradas produtivas para o desenvolvimento das teorias sobre a motivação, época em que foram construídas: a teoria das necessidades de Maslow (1943), a teoria das necessidades (afiliação, poder e realização) de McClelland (1953), a teoria ERC (existência, relacionamento e crescimento) de Alderfer (1969) e a teoria bifatorial de Herzberg, Mausner e Snyderman (1959), apud GONDIM e SILVA (2004).

Provavelmente, o modelo de motivação mais difundido e mais importante seja o estudo de Abraham Maslow, com a sua "Teoria da Hierarquia de Necessidades". De acordo 
com seus estudos: "apenas as necessidades não satisfeitas são fontes de motivação". (Montana \& Charnov, 1999:205)

Maslow citado em Montana \& Charnov (1999:205) afirmava que: "existem cinco sistemas responsáveis por grande parte do nosso comportamento". Ele colocou esses sistemas em uma escala hierárquica, indo do mais primitivo e imaturo para o mais civilizado e maduro: sobrevivência; proteção ou segurança; necessidade de pertencer a um lugar; estima ou ego; e auto-realização.

Necessidades fisiológicas ou biológicas: constituem o nível mais baixo de todas as necessidades humanas, como as necessidades de alimentação (fome e sede), de sono e repouso (cansaço), abrigo (frio ou calor), ou desejo sexual (reprodução da espécie). Estas necessidades são relacionadas com a própria subsistência e existência do indivíduo.

Necessidades de segurança: constituem o segundo nível das necessidades humanas. Levam a pessoa a proteger-se de qualquer perigo real ou imaginário, físico ou abstrato: a busca de proteção contra a ameaça ou privação, a fuga ao perigo, o desejo de estabilidade, a busca de um mundo ordenado e previsível são manifestações típicas destas necessidades. Surgem no comportamento humano quando as necessidades fisiológicas estão relativamente satisfeitas.

Necessidades sociais: são as necessidades relacionadas com a vida associativa do indivíduo com outras pessoas. São as necessidades de associação, de participação, de aceitação por parte dos colegas, de troca de amizade, de afeto e amor. Surgem quando as necessidades mais baixas (fisiológicas e segurança) se encontram relativamente satisfeitas. Quando as necessidades sociais não estão suficientemente satisfeitas, a pessoa se torna 
resistente, antagônica e hostil com relação às pessoas que a cercam e as conduzem geralmente à falta de adaptação social e à solidão.

Necessidades de estima: são necessidades relacionadas com a maneira pela qual a pessoa se vê e se avalia, isto é, com a auto-avaliação e auto-estima. Envolve a autoapreciação, a autoconfiança, a necessidade de aprovação social e de reconhecimento, de status, prestígio e de consideração. A satisfação dessas necessidades conduz a sentimentos de autoconfiança, de valor, força, prestígio, poder, capacidade e utilidade. A sua frustração pode produzir sentimentos de inferioridade, fraqueza, dependência e desamparo, os quais, por sua vez, podem levar ao desânimo ou à atividade compensatória.

Necessidades de auto-realização: são as necessidades humanas mais elevadas e que se encontram no topo da hierarquia. São necessidades que levam cada pessoa a realizar o seu próprio potencial e de se desenvolver continuamente ao longo da vida. Essas necessidades estão relacionadas com a plena realização daquilo que cada pessoa tem de potencial e de virtual, da utilização plena dos talentos individuais.

De acordo com Maslow: "existe uma tendência natural pela qual os indivíduos se tornam cientes de cada uma dessas necessidades, sendo assim motivados por elas em ordem ascendente" (Montana \& Charnov, 1999:205). Progredir na hierarquia de Maslow pode ser comparado a subir um degrau de uma escada por vez; estar ciente do próximo degrau pressupõe uma negociação bem-sucedida do degrau anterior.

Maslow não teve a intenção de dizer que qualquer necessidade sempre recebe uma satisfação completa. Pelo contrário, ele acreditava que é preciso um mínimo de satisfação antes que uma necessidade deixe de preocupar a pessoa à exclusão de outras, mais elevadas. Uma vez alcançado esse ponto, a pessoa ficará livre para sentir as tensões associadas com o 
próximo nível da hierarquia e para experimentar um novo conjunto de comportamentos feitos para satisfazer a nova necessidade.

Ainda citando a teoria de Maslow (Gondim e Silva, 2004) dizem que se baseia muito em sua experiência clínica partindo da premissa de que as necessidades humanas têm origem biológica e estão dispostas em uma hierarquia que deixa implícito o pressuposto antropológico de que o homem tem uma propensão para o autodesenvolvimento e o crescimento pessoal. Para que esse desenvolvimento possa ter livre curso, é preciso que as necessidades inferiores sejam em parte satisfeitas e as necessidades superiores apresentem-se como motivadoras da conduta humana. As inferiores seriam as necessidades fisiológicas (indispensáveis à sobrevivência do indivíduo e da espécie) e as de segurança (vinculadas à proteção contra perigos e ameaças externas). As superiores, por sua vez, seriam as necessidades sociais (atinentes ao pertencimento e aceitação de outras pessoas e grupos humanos), as de estima (busca de status e valorização social) e as de auto-realização (condição máxima de crescimento pessoal e de busca contínua pelo auto-aperfeiçoamento). É de se observar que a grande maioria dos servidores que ingressam no Tribunal justamente o faz para buscarem valorização social visando um crescimento pessoal.

Seguindo a mesma linha de raciocínio de Maslow, no final da década de 1960 Alderfer (citado por Gondim e Silva, 2004) redefiniu as cinco necessidades hierarquizadas e as agrupou em três (ERC):

Existência (E), que inclui as necessidades fisiológicas e de segurança.

Relacionamento (R), que reúne as necessidades sociais e de estima.

Crescimento (C), que equivale à necessidade de auto-realização.

Além disso, Alderfer, afirmou, ao contrário de Maslow, que a motivação da conduta humana não obedeceria a um sentido apenas progressivo, mas também regressivo, ou seja, descendente. A frustração encontrada na satisfação de necessidades mais elevadas ou abstratas poderia fazer com que a pessoa regredisse no nível anterior (necessidades mais concretas) em que tenha conseguido bons resultados (Muchinsky, 1994). Chamou atenção também para o fato de que duas necessidades poderiam conjuntamente estar influenciando a orientação da ação da pessoa, o que enfraqueceria a tese de que haveria uma hierarquia de necessidades. 
A teoria e a prática da motivação têm estado conosco por muito tempo. A motivação pode causar aumentos substanciais na produtividade e na satisfação no trabalho, além de substanciais reduções nas faltas, nos atrasos, nos agravos e daí por diante.

No processo de motivação, as necessidades não satisfeitas criam tensão, que levam a atividades direcionadas a satisfazer a necessidade humana de reduzir a tensão. A motivação pode ser descrita como o processo de estimular o indivíduo a tomar ações que levarão ao preenchimento de uma necessidade ou à realização de uma meta desejada.

Frederick I. Herzberg usou uma abordagem um tanto diferente para a motivação. Maslow se preocupava com as fontes de motivação no sentido da vida em geral, enquanto Herzberg focalizou as fontes de motivação que pareciam estar relacionadas ao trabalho e às realizações no trabalho. Mesmo assim, as investigações de Herzberg o levaram a concluir que necessidades bastante similares às sugeridas por Maslow estavam operando no contexto do trabalho.

Herzberg essencialmente observou que apenas os sistemas de necessidades que correspondem aos níveis de estima e auto-realização de Maslow servem como fontes diretas de motivação para se trabalhar com eficácia. Ele descobriu que a necessidade de pertencer está, de certa maneira, ligada à motivação para trabalhar, especialmente na área dos relacionamentos entre o supervisor e o subordinado, e a questões relacionadas com as satisfações pessoais. Essas necessidades na parte superior da hierarquia de Maslow foram chamadas, por Herzberg, de fatores de motivação ou satisfação.

Os sistemas das necessidades inferiores, especialmente as básicas que dizem respeito às necessidades fisiológicas e de segurança, foram chamados por Herzberg de fatores de 
insatisfação, em vez de fontes de motivação no trabalho. Ele acreditava que o ato de pertencer sobrepunha ambos os grupos.

Herzberg achava que: "os fatores de motivação do nível superior levavam a comportamentos diretamente relacionados ao trabalho a ser feito, enquanto os fatores de insatisfação dos níveis inferiores promoviam comportamentos que focalizavam assuntos periféricos ao trabalho em si" (Montana \& Charnov, 1999). Além disso, Herzberg concluiu que, mesmo que as necessidades dos níveis inferiores fossem satisfeitas, ainda assim não haveria razão para esperar que as pessoas trabalhassem com mais eficácia, pois as necessidades dos níveis inferiores servem primariamente como fatores de higiene ou manutenção, aquelas que as pessoas acreditam que, em sua maioria, serão satisfeitas.

A Teoria de McClelland, citada por Gondim e Silva, 2004, embora também trate as necessidades como de origem biológica, não as considera pela perspectiva de hierarquia. Afirma que há três tipos de necessidades, poder, afiliação e realização -, que se interrelacionam e se apresentam em níveis variados de intensidade nas pessoas, conforme seus perfis psicológicos e os processos de socialização aos quais estiveram submetidas. Quando a necessidade de realização prepondera, a pessoa evidencia alta motivação para a autorealização e a busca de sua autonomia, assumindo, inclusive, desafios realísticos no trabalho e lutando continuamente pelo seu sucesso pessoal. Quando a necessidade mais forte é a da afiliação, a pessoa centra sua atenção na manutenção de seus relacionamentos interpessoais, muitas vezes em detrimento de seus interesses individuais. Estar mais próximo do outro e ser aceito por ele é o que orienta sua ação. Por último, quando a necessidade de poder é a que está mais desenvolvida, a pessoa se sente motivada pelo desejo de influenciar, reorientar e mudar as atitudes e as condutas alheias.

A motivação no trabalho irá depender da qualidade dos arranjos entre esses três tipos de necessidades. Espera-se, por exemplo, que um líder e gerente apresentem tanto uma alta necessidade de poder, visto que precisará influenciar pessoas, quanto uma moderada necessidade de afiliação, uma vez que sua liderança ficará ameaçada caso não procure ser 
aceito e reconhecido pelos membros do grupo (McClelland e Burnham, 1997, citados por GONDIM e SILVA, 2004).

O estudo de McClelland diz que: "existem certas necessidades que são aprendidas e adquiridas socialmente através da interação com o meio ambiente" (Montana \& Charnov, 1999). Sua teoria considera três motivos: a necessidade de realização, a necessidade de poder e a necessidade de afiliação.

De acordo com McClelland: "as pessoas que demonstram forte necessidade de realização são particularmente responsivas aos ambientes de trabalho nos quais podem atingir o sucesso através de seus próprios esforços. Na realidade, a motivação pela realização é, em grande parte, uma teoria para empreendedores" (Montana \& Charnov, 1999).

O papel da motivação pelo poder é apoiado pelos estudos da AT\&T, que segue os graus promocionais de gerentes com padrões de motivos diferentes. Por outro lado, McClelland vê a motivação pela afiliação como um fator negativo no desempenho gerencial, pois tendem a fazer com que o gerente fique subjetivamente preocupado com os indivíduos, interferindo assim com a objetividade e a racionalidade.

B. F. Skinner diz que: "o comportamento reforçado será repetido, e que o comportamento não reforçado tem menos chance de ser repetido. Por exemplo, se um indivíduo é promovido por ter aumentado as vendas substancialmente, é muito provável que ele continue a aumentá-las substancialmente para ter outra promoção" (Montana \& Charnov, 1999). A teoria do reforço presume que as conseqüências do comportamento de uma pessoa determinam o nível de motivação. 
A maior força motivadora na teoria da eqüidade é a luta pela igualdade, que emerge apenas depois que alguma desigualdade ou injustiça é percebida. A eqüidade envolve uma comparação com o desempenho contra as recompensas que outros receberam por trabalhos similares.

Em 1960, Douglas McGregor salientou a importância da compreensão dos relacionamentos entre a motivação e o comportamento. Ele acreditava que os gerentes motivam os funcionários através de duas abordagens básicas, denominadas teoria $\mathrm{X}$ e teoria Y. A visão tradicional, a teoria $\mathrm{X}$, sugere que os gerentes devem coagir, controlar e ameaçar os funcionários para poder motivá-los. A filosofia alternativa da natureza humana era a da teoria Y, que acredita que as pessoas são capazes de ser responsáveis. Elas não precisam ser coagidas ou controladas pelo gerente para ter um bom desempenho.

As Teorias X e Y de McGregor (1960), citada por Gondim e Silva, 2004, muito referidas em textos que discutem o tema motivação, a rigor, não trouxeram uma nova perspectiva de entendimento da motivação humana no trabalho. Ao contrário, partiram do estudo da prática administrativa norte-americana para analisar criticamente as concepções da natureza humana que estavam implícitas nestes modelos de gerenciamento. McGregor(1960) afirmou que a maioria dos administradores norte-americanos sustentava suas ações de gerenciamento em uma concepção negativa da relação do homem com o trabalho.

A Teoria X, primeira a ser formulada por McGregor, apoiava-se em três princípios básicos: o homem tem aversão ao trabalho; precisa ser controlado e punido para que se esforce e cumpra os objetivos organizacionais, assim como evita a responsabilidade, pois está interessado apenas na sua segurança pessoal e financeira. A conclusão de McGregor foi a de que a prática gerencial apoiada na teoria $\mathrm{X}$ ignorava os estudos da motivação desenvolvidos por Maslow, que ressaltavam o quanto à motivação seria decorrente da emergência de necessidades humanas dispostas hierarquicamente.

Outra parte dos administradores pensava diferente, por influência da difusão da teoria das relações humanas. A esse modo alternativo de pensar, McGregor chamou de teoria Y, 
cujos princípios seriam: o trabalho pode ser uma fonte de satisfação ou punição, dependendo do contesto; o homem está disposto a se autodirigir, a aprender a aceitar responsabilidades e também a colocar em prática o seu potencial criativo. Em resumo, a teoria Y trouxe à tona o reconhecimento de que o desempenho do homem no trabalho é um problema mais de natureza gerencial do que motivacional, aspecto já defendido por Argyris no livro Personalidade e organização (1957).

A Teoria Bifatorial de Herzber, Mausner e Snyderman(1959), citada por Gondim e Silva, 2004, foi formulada a partir da análise das descrições de pessoas sobre o que desejavam obter com o seu trabalho, com destaque para o que as fazia se sentir bem ou mal nesse contexto. A categorização das respostas permitiu aos autores separar aquelas relacionadas diretamente com a satisfação no trabalho das relacionadas à satisfação localizavam-se na pessoa ou nas próprias tarefas. Ao contrário, os fatores relacionados à insatisfação localizavam-se externamente à pessoa, tais como na política e na administração da empresa, no estilo de supervisão, no relacionamento com os colegas e nas recompensas e benefícios recebidos. Com base nisto, a teoria da motivação bifatorial foi construída afirmando haver dois conjuntos de fatores que variavam em dois contínuos independentes: o primeiro, seria o dos fatores higiênicos, referentes a fatores externos, que variava da condição de insatisfação à não-insatisfação; o segundo conjunto de fatores seria o dos motivadores, referente a fatores internos, que oscilava da condição de satisfação à não-satisfação.

Kanfer (1992), citado por Gondim e Silva, 2004, faz uma crítica às teorias da motivação baseadas no conceito de necessidade, ao levar em conta a reorientação da ação da pessoa. A autora afirma que identificar a necessidade (o conteúdo da motivação) seria insuficiente para orientar a conduta humana, uma vez que a pessoa pode não dispor da informação sobre os passos a serem tomados para satisfazê-la.

A Teoria da Expectância (VIE) de Vroom (1995), que basicamente foi o pilar do presente estudo, concebe a motivação fundamentalmente como uma força de natureza emocional e consciente, que é ativada no momento em que a pessoa é levada a escolher entre diversos planos de ação. A força dessa escolha estaria relacionada a dois fatores, expectativas individuais e avaliação subjetiva das conseqüências esperadas por meio da comparação entre várias alternativas de ação. A suposição de Vroom é a de que as pessoas decidem sobre suas ações de modo instrumental, procurando maximizar seu prazer e seus ganhos e minimizar seu desprazer e suas perdas. A valência é uma atribuição de qualidade positiva ou negativa aos 
resultados pretendidos. É o que faz com que a pessoa esteja orientada afetivamente para a busca de um resultado. Em outras palavras, é o que faz com que uma pessoa sinta atração ou repulsa, por exemplo, por uma promoção. A instrumentalidade é a força ou a clareza da relação percebida entre a ação a ser empreendida e a obtenção do resultado esperado. Por último, a expectância é a intensidade com que uma pessoa é capaz de antecipar os resultados esperados e visualizar sua concretização (Borges; Alves Filho, 2001). Com a pesquisa desenvolvida no STJ procurarei medir, também, o que os servidores esperam da instituição e se realmente há a concretização do esperado.

A Teoria do Estabelecimento de Metas (Locke e Lathan,1990), citada por Gondim E Silva, sustenta a premissa de que as metas variam em conteúdo e intensidade. De acordo com o conteúdo, podem ser fáceis ou difíceis, específicas ou gerais e simples ou complexas. A intensidade, por sua vez, pode variar conforme a percepção da importância do comprometimento com a meta.

A Teoria da Avaliação Cognitiva de Deci (1971), citada por Gondim e Silva, 2004, afirma que as pessoas tendem a avaliar as suas ações com base nas atribuições que fazem de suas causas ou razões. Atribuir o controle do desempenho individual no trabalho a fatores da própria pessoa ou a fatores externos influencia na avaliação que cada um faz de sua motivação.

Spector (2008) afirma que as teorias de motivação no trabalho normalmente se preocupam mais com as razões do que com as habilidades que levam certos indivíduos a realizar suas tarefas melhor do que os outros. As teorias apresentadas por ele vêem a motivação dos funcionários a partir de perspectivas muito diferentes. Dependendo da situação, essas teorias como já mencionaram antes, pelo autor, podem prever as escolhas de comportamento para a tarefa, o esforço ou a persistência dessas pessoas. São as seguintes teorias:

Teoria das necessidades - Entende a motivação como resultante dos desejos pessoais por determinadas coisas. Considera-se que as necessidades podem ser diferentes tanto para a mesma pessoa ao longo do tempo quanto entre pessoas diferentes. A teoria da hierarquia das necessidades se preocupa com as variações nas necessidades interiores dos indivíduos ao longo do tempo. 
Teoria da Hierarquia das Necessidades - A satisfação das necessidades humanas é importante para a saúde física e mental do indivíduo, pois elas estão dispostas em uma hierarquia que inclui necessidades físicas, sociais e psicológicas. O nível mais baixo inclui as necessidades quanto à sobrevivência, como ar, água, comida. O segundo nível consiste nas necessidades de segurança quanto à proteção de possíveis perigos, como as relacionadas a abrigo e proteção. No terceiro nível, estão as necessidades sociais, que incluem amor, afeição e relacionamento com outras pessoas. O quarto nível é o da necessidade de estima, que envolve o respeito a si próprio e aos outros.

Teoria dos dois fatores (ou teoria da motivação-higiene) - Afirma que a motivação resulta da natureza do trabalho em si, e não de recompensas externas ou das condições de trabalho. As necessidades humanas no trabalho estão divididas em duas categorias - as derivadas da natureza animal dos seres humanos, como as necessidades físicas, e as que são relacionadas a um nível mais elevado, habilidade única dos humanos para o crescimento psicológico. Os aspectos do trabalho relevantes às necessidades de natureza animal são chamados fatores de higiene e incluem salário, supervisão, companheiros de trabalho e políticas organizacionais. Os aspectos do trabalho importantes para as necessidades de crescimento são chamados fatores de motivação e incluem realização, reconhecimento, responsabilidade e a natureza do trabalho em si.

Teoria do reforço - Descreve como recompensas ou reforços podem afetar o comportamento. A teoria não lida com estados internos como a motivação; então, de certa forma, essa é uma teoria não motivacional. Ela explica o comportamento como função de experiências recompensadoras anteriores ou histórico de reforço. O comportamento é visto como uma resposta ao ambiente. O princípio mais importante da teoria do reforço é a lei do efeito. Ela declara que a probabilidade da ocorrência de um determinado comportamento aumenta se for seguida por uma recompensa; inversamente, a probabilidade de um comportamento diminui se ele for seguido de punição.

Teoria da auto-eficácia - Afirma que a motivação e o desempenho são em parte determinados pela crença das pessoas sobre o quanto elas podem ser eficientes. O conceito de auto-eficácia em si está ligado a tarefas específicas ou determinadas ações, e a auto-eficácia das pessoas pode variar de uma tarefa para outra. É muito parecido com o de expectativa. A principal diferença é que a expectativa se relaciona a uma atividade específica em um dado 
momento, enquanto a auto-eficácia se preocupa com a sensação de que uma pessoa é capaz ou não de fazer algo, como jogar tênis.

Teorias de Justiça - Uma abordagem diferente à motivação é propiciada pelas teorias de justiça as quais estão voltadas para o tratamento justo dos funcionários por suas organizações. O pressuposto subjacente dessas teorias é que as pessoas valorizam a justiça e que são motivadas a mantê-la nos relacionamentos entre elas mesmas e as organizações. A teoria da eqüidade afirma que as pessoas são motivadas a alcançar uma condição de igualdade ou justiça nas suas relações com outras pessoas e com as organizações.

Teoria da fixação de Metas - O princípio básico dessa teoria diz que o comportamento das pessoas é motivado por suas intenções e seus objetivos, que podem estar intimamente relacionados a comportamentos específicos. Segundo essa teoria, a meta é aquilo que uma pessoa conscientemente deseja obter. A teoria da fixação de metas é sustentada por pesquisas, e é atualmente a teoria de motivação mais popular dentro da psicologia organizacional.

Teoria do Controle - Apóia-se sobre a teoria da fixação de metas, focalizando a forma como o feedback afeta a motivação para manter o esforço rumo às metas. O processo explicado pela teoria começa com uma meta que a pessoa pretende realizar. A meta pode ser atribuída por um supervisor ou simplesmente escolhida pela própria pessoa, mas a teoria sustenta que a pessoa deve acreditar que a meta é alcançável e aceitá-la. Com o passar do tempo, enquanto a pessoa trabalha rumo à meta, lhe é dado feedback sobre seu desempenho.

Teoria da ação - É uma teoria alemã abrangente sobre o comportamento do trabalho que descreve um processo que vincula metas a comportamentos. Essa teoria propõe que as teorias de motivação para o trabalho devem concentrar-se principalmente em comportamentos orientados para metas ou comportamentos volitivos (voluntários) chamados ações. Tais ações são resultado de uma intenção consciente de realizar alguma coisa, que pode ser pequena como a conclusão de uma peça numa linha de montagem ou obter uma promoção no trabalho. O principal foco dessa teoria consiste nas próprias ações e nos processos que levam às ações.

Ao discorrer sobre participação, Siqueira (2006) afirma que evidências do pensamento taylorista dão conta que o que mais motiva o empregado é a remuneração. Como frutos desse pensamento estão os modelos de pagamento dos empregados, tais como a participação em ações, à remuneração por habilidade e remuneração variável. Afirma ainda que de uns tempos para cá premiam-se quem realmente pode alcançar os resultados desejados pela empresa. No 
resultado do estudo, no STJ não se foge muito à regra, visto que muitos servidores buscam sua motivação na remuneração e seguem querendo um maior aumento baseados em gratificações maiores que possam aumentar seus salários.

Com o objetivo de desenvolver um estudo para saber quais ou quais teorias melhor se adéquam ao perfil motivacional dos servidores do Superior Tribunal de Justiça utilizarei o Inventário da Motivação e do Significado do Trabalho (IMST) que foi criado pensando, também, em melhor equipar os profissionais e pesquisadores com um instrumento confiável sobre os construtos referidos na sua designação. Sua elaboração (Borges e Alves Filho, 2001) ocorreu a partir da ampliação do Inventário do Significado do Trabalho ([IST] Borges, 1997, 1999), pela absorção de conceitos da teoria da motivação designada como Teoria das Expectativas (Vroom, 1964, 1969) e das categorias empíricas levantadas por meio de entrevistas. Ao contar sobre o trabalho em quanto ele nos desafia, o quanto provêm nosso sustento e as nossas relações interpessoais temos a oportunidade de revelar as características descritivas que atribuímos ao trabalho.

Quanto à sua forma, o IMST inicia-se por uma apresentação, seguida das instruções, nas quais se trata dos objetivos, do anonimato do participante, do compromisso com o sigilo das respostas individuais, do conteúdo do questionário, da forma de respondê-lo e de exemplos de questões extras com o mesmo estilo das que serão respondidas. Em seguida, apresenta-se às expectativas e aos atributos descritivos, com sessenta e dois itens. Estão precedidas por nova instrução contendo exemplos de questões respondidas. Os itens expressam possíveis resultados do trabalho. O participante apresenta duas repostas para cada item: uma dizendo quanto espera que o resultado indicado no item ocorra (expectativa) e outra dizendo quanto observa aquele resultado na prática. Essas respostas também são apresentadas em uma escala de zero a quatro. 


\section{3- METODOLOGIA}

O presente trabalho fundamenta-se nas teorias da Motivação. O estudo visa permitir aos gestores e interessados uma melhor percepção a respeito da expectativa motivacional e o desempenho humano no trabalho dos servidores do STJ, bem como do suporte organizacional oferecido por elas aos seus colaboradores.

\subsection{TIPO DE PESQUISA}

Foi usado o critério de classificação proposto por Vergara (2000), podendo-se qualificar a pesquisa em dois aspectos: quanto aos fins e quanto aos meios de investigação.

Quanto aos fins, a pesquisa é descritiva e aplicada. Descritiva, pois compreende a obtenção e exposição de dados representativos de determinado fenômeno. Neste caso, descrevem-se as percepções dos servidores. Quanto aos fins, a pesquisa é aplicada, porque possui finalidade prática.

No que tange aos meios de investigação, a presente pesquisa é bibliográfica e de campo. Bibliográfica uma vez que compreende uma revisão da literatura acerca do tema, construída a partir do estudo de material publicado em livros, artigos, sítios da internet, etc. Ainda quanto aos meios, a pesquisa é de campo já que foi aplicado questionário aos servidores do STJ.

\subsection{POPULAÇÃO E AMOSTRA:}

O questionário foi aplicado a quarenta servidores, lotados nas diversas áreas do Tribunal e as características da amostra referentes ao sexo dos participantes, cargo de 
ocupação, idade, nível de escolaridade, tempo de serviço no STJ e faixa etária, são apresentadas a seguir e está demonstrado abaixo:

VARIÁVEL

Sexo

Masculino

Feminino
F \% VARIÁVEL

\section{Nível de Escolaridade}

18

45,0

22

55,0 Superior completo

Especializado
F $\quad \%$

820,0

2865,0

$6 \quad 15,0$

\section{Cargo}

Técnico judiciário

Analista judiciário

Analista administrativo

\section{Área de atuação}

$23 \quad 57,5$

$14 \quad 35,0$ Administrativa

$3 \quad 7,5$

$37,5 \quad J u d i c i a ́ r i a$

$7 \quad 17,5$

Órgãos Julgadores
Faixa etária

Menos de 1 ano

$6 \quad$ 15,0 De 1 a 5 anos

$14 \quad 35,0$ De 6 a 10 anos

1127,5 De 11 a 15 anos

7 17,5 De 16 a 20 anos

25,0 De 21 a 25 anos
$1 \quad 2,5$

1640,0

$15 \quad 37,5$

$4 \quad 10,0$

37,5

12,5 
A maioria da amostra é composta por participantes do sexo feminino $(55,0 \%)$ e possui de vinte e seis a trinta e três anos de idade (35,0\%). Em relação ao nível de escolaridade e tempo de serviço no STJ, grande parte dos respondentes possui curso superior completo (65,0\%) e estão de um a cinco anos no Tribunal (40,0\%).

Quanto aos cargos ocupados, grande parte dos servidores está lotada nos Órgãos Julgadores (75,0\%). Dos quarenta respondentes, vinte e três (57,5\%) são técnicos judiciários.

\subsection{PROCEDIMENTOS:}

As informações foram coletadas pessoalmente pelo pesquisador em caráter individual e no local de trabalho de cada servidor. O questionário contém sessenta e duas perguntas abertas contendo atribuições de pontos de zero a quatro quanto à expectativa do servidor e sessenta e duas perguntas abertas contendo atribuições de pontos de zero a quatro quanto à ocorrência.

\subsection{ANÁLISE DAS INFORMAÇÕES:}

A análise do conteúdo das entrevistas foi feita com base no Inventário da Motivação e Significado do Trabalho (IMST) (Borges e Alves-Filho, 2001) e do professor orientador da monografia. 


\section{RESULTADOS E DISCUSSÃO}

Será apresentado a seguir o resultado obtido com os componentes da motivação:

A tabela 1 A apresenta como resultado a mensuração do item auto-expressão que indica o quanto o indivíduo espera encontrar oportunidades para sentir-se reconhecido, para expressar sua criatividade, seu bem-estar, a aprendizagem e as habilidades interpessoais, para opinar, para perceber proporcionalidade entre as retribuições das organizações e o que faz para ser respeitado como ser humano e merecer a confiança dos superiores e como tudo isso ocorre na Instituição.

\section{Itens}

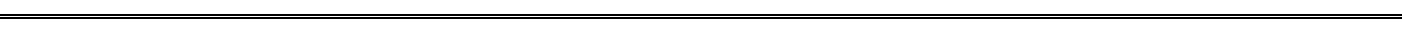

59. Influência nas decisões (contribuindo para a formação de opiniões).

1. Oportunidades de expressão de minha criatividade.

28. Oportunidades permanentes de aprendizagem de novas coisas.

58. Desenvolvimento das minhas habilidades interpessoais.

51. Sentimento de estar bem de cabeça (mentalmente).

14. Minhas opiniões levadas em conta.

46. Sentimento de que sou gente.

50. Merecimento de ganhar mais pelo que faço.

57. A percepção de ser produtivo.

15. A confiança dos chefes em mim.

43. Igualdade de direitos para todos que trabalham.

12. O sentimento de ser tratado como pessoa respeitada.

$3,65 \quad 0,58$

Tabela 1 A - Resultados quanto às expectativas dos servidores em relação a auto-expressão. 
A tabela $1 \mathrm{~B}$ demonstra a mensuração do item auto-expressão, que indica o quanto o indivíduo percebe que ocorrem os itens analisados na tabela $1 \mathrm{~A}$.

\begin{tabular}{|c|c|c|}
\hline Itens & Média & $\begin{array}{l}\text { Desvio } \\
\text { Padrão }\end{array}$ \\
\hline 59. Influência nas decisões (contribuindo para a formação de opiniões). & 2,52 & 1,06 \\
\hline 1. Oportunidades de expressão de minha criatividade. & 2,45 & 1,28 \\
\hline 28. Oportunidades permanentes de aprendizagem de novas coisas. & 2,90 & 0,98 \\
\hline 48. Reconhecimento pelo que faço. & 3,05 & 0,90 \\
\hline 58. Desenvolvimento das minhas habilidades interpessoais. & 2,70 & 0,88 \\
\hline 51. Sentimento de estar bem de cabeça (mentalmente). & 3,05 & 1,10 \\
\hline 14. Minhas opiniões levadas em conta. & 2,53 & 1,15 \\
\hline 46. Sentimento de que sou gente. & 3,05 & 0,98 \\
\hline 50. Merecimento de ganhar mais pelo que faço. & 2,85 & 0,98 \\
\hline 57. A percepção de ser produtivo. & 2,85 & 0,73 \\
\hline 15. A confiança dos chefes em mim. & 3,22 & 0,86 \\
\hline 43. Igualdade de direitos para todos que trabalham. & 2,10 & 1,44 \\
\hline 12. O sentimento de ser tratado como pessoa respeitada. & 3,22 & 0,73 \\
\hline
\end{tabular}

Tabela 1 B - Resultados do quanto ocorre na pesquisa em relação à auto-expressão.

Partindo da análise confrontante das duas tabelas, observa-se que o servidor do Superior Tribunal de Justiça, dentro da amostragem desse estudo, demonstra uma confortável influência nas decisões, visto que a grande maioria dos pesquisados encontra-se nos Órgãos Julgadores e o servidor, ao exercer o seu papel judicante, faz com que as suas decisões influenciem, por exemplo, em um andamento processual mais célere. $\mathrm{O}$ sentimento constante nos itens da tabela esboça claramente a expressividade de sua criatividade e suas habilidades interpessoais. Um item que merece um destaque é o da igualdade de direitos para todos que trabalham que está em um patamar mediano, merecendo atenção no sentido da proporcionalidade dos direitos igualitários entre todos que trabalham. Portanto, a medição da auto-expressão no STJ está de acordo com os objetivos desse estudo e com as finalidades do Tribunal. 
A tabela 2 A apresenta como resultado a mensuração do item componente da motivação desgaste e desumanização, que indica o quanto o servidor espera encontrar de que o trabalho venha resultar em esgotamento, pressa, atarefamento, exigência de rapidez, desproporção entre esforços e recompensas, negação da própria condição humana, discriminação, esforço corporal e repetição de tarefas e como tudo isso acontece na prática.

\section{Itens}

45. Sentimento de que estou esgotado.

37. Uma vida corrida, quando se trabalha também em casa.

40. Sentimento de ser como uma máquina ou um animal.

23. Dureza, pela exigência de esforço, dedicação e luta.

56. Pressa em fazer e terminar as minhas tarefas.

22. Esforço físico (corporal) na execução do trabalho.

52. Exigência de rapidez.

42. Discriminação pelo meu trabalho.

35. Tarefas parecidas diariamente feitas.

10. Repetição diária de tarefas.

47. Percepção de que estou atarefado.

44. Percepção de quem ganha pouco para o esforço que faço.

$1,30 \quad 1,65$

Tabela 2 A - Resultados quanto às expectativas dos servidores em relação ao desgaste e desumanização. 
A tabela 2 B demonstra a mensuração do item desgaste e desumanização, que indica o quanto o indivíduo percebe que ocorrem os itens analisados na tabela $2 \mathrm{~A}$.

\begin{tabular}{lrc}
\hline \hline \multicolumn{1}{c}{ Itens } & Média $\begin{array}{c}\text { Desvio } \\
\text { Padrão }\end{array}$ \\
\hline \hline 45. Sentimento de que estou esgotado. & 2,38 & 1,39 \\
37. Uma vida corrida, quando se trabalha também em casa. & 2,90 & 1,12 \\
40. Sentimento de ser como uma máquina ou um animal. & 2,25 & 1,41 \\
23. Dureza, pela exigência de esforço, dedicação e luta. & 2,50 & 1,13 \\
56. Pressa em fazer e terminar as minhas tarefas. & 2,85 & 0,86 \\
22. Esforço físico (corporal) na execução do trabalho. & 2,85 & 0,86 \\
52. Exigência de rapidez. & 3,17 & 0,84 \\
42. Discriminação pelo meu trabalho. & 1,37 & 1,29 \\
35. Tarefas parecidas diariamente feitas. & 3,33 & 0,76 \\
10. Repetição diária de tarefas. & 3,22 & 0,69 \\
47. Percepção de que estou atarefado. & 2,83 & 0,90 \\
44. Percepção de quem ganha pouco para o esforço que faço. & 1,72 & 1,46
\end{tabular}

Tabela 2 B - Resultados do quanto ocorre na pesquisa em relação ao desgaste e desumanização.

Comparando-se as duas tabelas percebe-se que a expectativa dos servidores retrata o que realmente ocorre no sentido de se ter uma repetição do trabalho, uma vez que determinados serviços requerem de fato essa repetição, tais como numerar folhas de processos, publicação de várias decisões, geralmente com os mesmos procedimentos. E pelo grande volume de trabalho exige-se em contrapartida, uma maior rapidez por parte do servidor causando uma percepção de estar quase sempre atarefado. Nota-se, também, que o servidor não deseja uma discriminação pelo seu trabalho e que isto não ocorre. 
A tabela 3 A apresenta como resultado a mensuração do item da responsabilidade, que indica o quanto o servidor espera encontrar no tocante ao cumprimento das tarefas e das obrigações, à responsabilidade pelas próprias decisões, ao sentimento de dignidade, à apresentação de atitudes de obediência e a manter-se ocupado e a ocorrência desses fatores.

\begin{tabular}{lrc}
\hline \multicolumn{1}{c}{ Itens } & Média $\begin{array}{c}\text { Desvio } \\
\text { Padrão }\end{array}$ \\
\hline \hline 38. Assistência para mim e para minha família. & $3,720,50$ \\
29. Responsabilidade por minhas decisões. & $3,60 \quad 0,63$ \\
26. Sentimento de que sou uma pessoa digna. & $3,70 \quad 0,64$ \\
34. Obediência aos superiores. & $3,720,45$ \\
19. Responsabilidade para enfrentar os problemas do trabalho. & $3,520,78$ \\
39. Tarefas e obrigações de acordo com minhas possibilidades. & $3,45 \quad 0,87$ \\
36. Percepção de estar ocupado, fazendo alguma coisa. & $2,97 \quad 1,16$ \\
21. Ocupação de meu tempo. & $3,20 \quad 0,75$
\end{tabular}

Tabela 3 A - Resultados quanto às expectativas dos servidores em relação às responsabilidades. 
A tabela 3 B demonstra a mensuração do item da responsabilidade, que indica o quanto o indivíduo percebe que ocorrem os itens analisados na tabela $3 \mathrm{~A}$.

\begin{tabular}{lrc}
\hline \hline \multicolumn{1}{c}{ Itens } & Média $\begin{array}{c}\text { Desvio } \\
\text { Padrão }\end{array}$ \\
\hline 38. Assistência para mim e para minha família. & 3,30 & 0,85 \\
29. Responsabilidade por minhas decisões. & $3,150,97$ \\
26. Sentimento de que sou uma pessoa digna. & $3,45 \quad 0,71$ \\
34. Obediência aos superiores. & $3,350,73$ \\
19. Responsabilidade para enfrentar os problemas do trabalho. & $3,220,86$ \\
39. Tarefas e obrigações de acordo com minhas possibilidades. & $3,08 \quad 0,99$ \\
36. Percepção de estar ocupado, fazendo alguma coisa. & $3,40 \quad 0,70$ \\
21. Ocupação de meu tempo. & $3,28 \quad 0,81$
\end{tabular}

Tabela 3 B - Resultados do quanto ocorre na pesquisa em relação às responsabilidades.

Verifica-se, pela análise das tabelas, uma quase perfeita consonância entre as expectativas e o que realmente ocorre no STJ, dentro do universo pesquisado. 
A tabela 4 A apresenta como resultado a mensuração do item da independência econômica, que indica o quanto o servidor espera encontrar que o trabalho proveja o sustento e a independência econômica, garanta contrapartidas merecidas, estabilidade no emprego, assistências e a própria sobrevivência e a ocorrência desses fatores.

\begin{tabular}{lr}
\hline \hline \multicolumn{1}{c}{ Itens } & Média $\begin{array}{c}\text { Desvio } \\
\text { Padrão }\end{array}$ \\
\hline \hline 5. Meu sustento. & $3,820,38$ \\
6. Independência para assumir minhas despesas pessoais. & $3,750,43$ \\
9. Retorno econômico merecido. & $3,520,71$ \\
7. Estabilidade no emprego. & $3,670,57$ \\
18. Assistência em transporte, educação, saúde, moradia, aposentadoria e etc. & $3,550,71$ \\
3. Reconhecimento da importância do que faço. & $3,30 \quad 0,82$ \\
17. Independência para decidir o que compro para mim. & $3,62 \quad 0,58$ \\
30. Minha sobrevivência. & $3,55 \quad 0,63$
\end{tabular}

Tabela 4 A - Resultados quanto às expectativas dos servidores em relação à independência econômica. 
A tabela 4 B demonstra a mensuração do item da independência econômica, que indica o quanto o indivíduo percebe que ocorrem os itens analisados na tabela $4 \mathrm{~A}$.

\begin{tabular}{|c|c|c|}
\hline Itens & Média & $\begin{array}{l}\text { Desvio } \\
\text { Padrão }\end{array}$ \\
\hline 5. Meu sustento. & 3,10 & 1,10 \\
\hline 6. Independência para assumir minhas despesas pessoais. & 3,40 & 0,74 \\
\hline 9. Retorno econômico merecido. & 2,98 & 1,02 \\
\hline 7. Estabilidade no emprego. & 3,57 & 0,87 \\
\hline 18. Assistência em transporte, educação, saúde, moradia, aposentadoria e etc. & 3,00 & 0,78 \\
\hline 3. Reconhecimento da importância do que faço. & 2,42 & 0,98 \\
\hline 17. Independência para decidir o que compro para mim. & 3,37 & 0,86 \\
\hline 30. Minha sobrevivência. & 3,33 & 0,88 \\
\hline
\end{tabular}

Tabela 4 B - Resultados do quanto ocorre na pesquisa em relação à independência econômica.

Observa-se, nesse item, a sintonia entre o que o servidor espera e o que ocorre. Isso se explica pelo fato de o STJ oferecer um plano de saúde eficiente, a estabilidade no serviço público, transporte de qualidade, auxílio-alimentação adequado, oportunidades de aprimoramento do seu quadro tanto oferecendo cursos dentro da Instituição como fora, por meio de bolsas de estudo para pós-graduação, convênios com a Fundação Getúlio Vargas, etc. 
A tabela 5 A apresenta como resultado a mensuração do item da segurança e dignidade, que indica o quanto o servidor espera encontrar que o trabalho proveja uma assistência merecida pelo trabalhador, os equipamentos necessários à execução das tarefas, segurança, higiene e conforto ambiental.

\begin{tabular}{|c|c|c|}
\hline Itens & Média & $\begin{array}{l}\text { Desvio } \\
\text { Padrão }\end{array}$ \\
\hline 54. Assistência merecida. & 3,63 & 0,66 \\
\hline 53. Equipamentos necessários e adequados. & 3,63 & 0,54 \\
\hline 41. Adoção de todas as medidas de segurança recomendáveis no meu trabalho. & 3,32 & 1,07 \\
\hline 49. Limpeza no ambiente de trabalho. & 3,42 & 0,93 \\
\hline $\begin{array}{l}\text { 27.Conforto nas formas de higiene, disponibilidade de materiais, equipamentos adequados e } \\
\text { conveniência de horário. }\end{array}$ & 3,55 & 0,74 \\
\hline
\end{tabular}

Tabela 5 A - Resultados quanto às expectativas dos servidores em relação à segurança e dignidade. 
A tabela 5 B demonstra a mensuração do item da segurança e dignidade, que indica o quanto o indivíduo percebe que ocorrem os itens analisados na tabela $5 \mathrm{~A}$.

\begin{tabular}{|c|c|c|}
\hline Itens & Média & $\begin{array}{l}\text { Desvio } \\
\text { Padrão }\end{array}$ \\
\hline 54. Assistência merecida. & 2,98 & 0,92 \\
\hline 53. Equipamentos necessários e adequados. & 2,85 & 0,94 \\
\hline 41. Adoção de todas as medidas de segurança recomendáveis no meu trabalho. & 2,73 & 1,21 \\
\hline 49. Limpeza no ambiente de trabalho. & 3,05 & 0,93 \\
\hline $\begin{array}{l}\text { 27.Conforto nas formas de higiene, disponibilidade de materiais, equipamentos adequados e } \\
\text { conveniência de horário. }\end{array}$ & 3,17 & 0,84 \\
\hline
\end{tabular}

Tabela 5 B - Resultados do quanto ocorre na pesquisa em relação à segurança e dignidade.

Observa-se que a expectativa do servidor, com relação ao item acima, confirma o que realmente ocorre. O STJ oferece uma ampla tecnologia proveniente da Secretaria de Informática, com computadores novos e com modernos recursos tecnológicos à disposição de seus servidores. Recentemente, com a implantação do processo de digitalização, máquinas digitalizadoras oferecem a celeridade necessária para o sucesso do projeto. Existe no Tribunal toda uma infra-estrutura com o objetivo de manter as medidas de segurança totalmente confiáveis, como a brigada de incêndio, por exemplo. Os servidores contam com um serviço de saúde altamente preparado com profissionais competentes tais como: médicos, enfermeiros, dentistas, psicólogos, assistentes sociais, creche, etc. 


\section{5 - CONCLUSÃO E RECOMENDAÇÕES}

O presente estudo objetivou investigar a expectativa motivacional no Superior Tribunal de Justiça. Para a consecução deste objetivo principal, foi construído um instrumento de pesquisa, submetido às análises semânticas e de conteúdo, para coletar as respostas dos participantes, a fim de identificar suas percepções acerca das motivações profissionais que expressam no desempenho de suas tarefas, bem como as percepções das ações concernentes ao suporte organizacional oferecido pela empresa. Primordial foi a utilização da consistência do inventário da motivação e do significado do trabalho - IMST que validou a pesquisa contendo perguntas sobre o trabalho em várias perspectivas: como deve ser (trabalho ideal), suas expectativas(o que todos esperam dele), como é na realidade e como se percebe o seu desempenho contribuindo para a obtenção de resultados desejados ou não.

Os resultados obtidos, de forma geral, mostraram uma motivação coerente com aquilo que a Instituição oferece a seus servidores e o que eles naturalmente desejam. As análises descritivas mostraram que os servidores percebem em que pontos desejam uma maior atenção, como exemplo, a repetição de suas tarefas que podem levar a um pequeno nível de ação motivadora. As médias e desvios-padrão encontrados dão validade, no nível individual, que os servidores respondem com homogeneidade, concordando entre si no que se refere ao desempenho motivacional em seu trabalho. As análises descritivas também revelam que a percepção de suporte organizacional é homogênea, ou seja, o Superior Tribunal de Justiça aplica ações que fazem com que seus servidores sintam-se reconhecidos com a livre iniciativa de expressarem suas criatividades, inclusive, oferecendo prêmios a quem apresentar idéias com a finalidade de facilitar os trabalhos, com o banco de idéias, podem opinar em pesquisas enviadas pela Intranet, conseguem sentir-se dignos com seu trabalho, capazes de ter independência econômica e terem condições materiais de trabalho satisfatória. 
As principais contribuições desse estudo mostram os pequenos níveis que merecem atenção com uma intervenção técnica com ações propiciadoras de suporte para uma maior elevado motivação que chegue a um alto nível de satisfação. Portanto, este trabalho contribui, como um instrumento, para que os gestores possam observar e aplicar ações no sentido de aumentar ainda mais a motivação dos servidores.

Algumas recomendações à Instituição podem ser feitas acerca das ações de suporte organizacional. Com base nos resultados, seria importante o desenvolvimento de medidas que dessem enfoque aos seguintes tópicos: padronização de tarefas entre as unidades, melhor distribuição das tarefas entre servidores antigos e novatos, medidas que evitem o desgaste físico, evitando assim o esgotamento, um conforto ambiental com ênfase nos espaços físicos dos locais de trabalho e uma maior valorização dos esforços dos servidores dando-lhe maiores oportunidades, ou seja, incentivos financeiros e oportunidades àqueles que realmente se dedicam, para que os que trabalhem muito não ficarem em desvantagem perante aos que fazem apenas o seu trabalho rotineiro, entre outros.

A pesquisa mostrou também um alto nível de escolaridade na Instituição, o que mostra a realidade, pois o STJ possui em seu quadro muitos servidores, em sua grande maioria, com o cargo de Técnico Judiciário (que exige o $2^{\circ}$ grau), mas que continuam seus estudos atingindo o nível superior e muito já até com nível superior ingressam no cargo de Técnico Judiciário já cursando a faculdade ou até mesmo com o $3^{\circ}$ grau completado.

Obviamente, o presente estudo apresenta suas limitações que restringem a generalização dos dados para outros contextos, uma vez que foi coletada junto a amostra de pequena escala, representativa apenas em poucos locais da Instituição. Seria importante realizar uma validação estatística do instrumento de pesquisa, o que não foi possível em razão do pequeno número de componentes da amostra. 
Considerando os resultados, as contribuições e as limitações do estudo, pode-se sugerir uma agenda de pesquisa:

1. Realização de mais pesquisas que contemplem a mensuração dos componentes da motivação, com um maior número de servidores e em mais diferentes setores, com aplicação continuada, pois a cada mês o Tribunal muda, seja com o volume de trabalho, seja com as expectativas de seus servidores.

2. Validação de uma escala abrangente que permita verificar a expressão das expectativas motivacionais e sua ocorrência.

3. Utilização de técnicas e procedimentos estatísticos mais sofisticados para garantir maior fidedignidade dos resultados de novos estudos; e

4. Avaliação das ações de suporte organizacional nas práticas motivacionais, para uma melhor compreensão do comportamento humano no trabalho.

Finalmente, espera-se que com esses pequenos estudos possam-se abrir caminhos para que a medição da satisfação e motivação dos servidores seja sempre analisada com muito carinho, pois estar motivado e feliz é o que todo servidor deseja. 


\section{6 - REFERÊNCIAS BIBLIOGRÁFICAS}

BERGAMIN, Cecília W. \& CODA, Roberto. Psicodinâmica da Vida Organizacional. São Paulo: Atlas, 1997. pp.323-326.

CHIAVENATO, Idalberto. Gerenciando pessoas. São Paulo: Makron Books,1999, $3^{\mathrm{a}}$ ed., pp.167-181

FREITAS, V. P. - Revista online de Administração - A cúpula dos Tribunais e a eficiência da Justiça, IBRAJUS, 2007. Disponível em:< http://www.ibrajus.org.br/revista/artigo.asp?idArtigo=43>. Acesso em: 16 ago. 2008.

GONDIM, S. M.G; SILVA, N. Motivação no Trabalho. In: ZANELLI, J.C.; BORGESANDRADE, J.E., BASTOS V.B. (Orgs.). Psicologia, organizações e trabalho no Brasil. Porto Alegre: Artmed, 2004. p.45 - 175.

HERSEY, Paul. \& BLANCHARD, Kenneth H. Psicologia para Administradores: A Teoria e as técnicas da Liderança Situacional. São Paulo: Pedagógica e Universitária, 1986, pp.1756,103-132,185-238.

LÉVY-LEBOYER, C. A crise das motivações: tradução Cecília Whitaker Bergamini, Roberto Coda. São Paulo: Atlas, 1994.

MINICUCCI, Agostinho. Psicologia Aplicada à Administração. São Paulo: Atlas, 1995, pp.213-246, 285-329.

MONTANA, Patrick J. \& CHARNOV, Bruce H. Administração. São Paulo: Saraiva 1999. pp.204-236.

MUCHINSKY, P. M. Psicología aplicada al trabajo: una introducción a la psicología industrial y organizacional. Bilbao: Desclée de Brouwer, 1994.

PEALE, N.V. Enthusiasm makes the difference (título do original americano) $\mathbf{O}$ poder do entusiasmo. New Jersey, U.S.A., 1967, Cap. 8 e 9, p. 157 - 192.

REIS, A. M. V.et al; TONET, H; BECKER JR., L.C.; COSTA, M.E.B. Desenvolvimento de equipes. Rio de Janeiro: editora FGV, 2007. Cap. 1 a 5, p. 14 - 138.

ROBBINS, Stephen P. Comportamento Organizacional. São Paulo: Atlas, 1998, $8^{\text {a }}$ ed., pps.109-142

SALANOVA, M., PEIRÓ, J.M. , HONTANGAS, P.M. Motivación laboral. Madrid: Síntesis, 1996, p.16.

SIQUEIRA, M. V. Gestão de pessoas e discurso organizacional: crítica à relação indivíduo-empresa nas organizações contemporâneas - Goiânia: Ed. Da UCG, 2006. 
SIQUEIRA, M.M (Org.) Medidas do comportamento organizacional: ferramentas de diagnóstico e de gestão, Porto Alegre : Artmed, 2008. Cap. 14, p. 215-248.

SPECTOR, E. PAUL . Psicologia nas organizações. Tradução da $4^{\mathrm{a}}$ edição americana. Tradução: Cid Knipel Moreira e Célio Kniple Moreira. Traduzido de Industrial and Organizational Psychology: research and pratice. Saraiva, 2008.

TAMAYO, A. Valores organizacionais, In: TAMAYO, A.; BORGES-ANDRADE, J. E.; CODO, W. (ORG.). Trabalho, organizações e cultura. São Paulo: Cooperativa de Autores Associados. 1996, p.175-193.

VROOM, V. Work and motivation. New York: John Wiley, 1964. 